\title{
Health Care Seeking Behaviour and Predictors of Combined Orthodox and Traditional Health Care Utilization among Households in Communities in Owerri, Imo State, Nigeria
}

\author{
Chukwuma B. Duru1, Anthony C. Iwu ${ }^{2 *}$, Kenechi A. Uwakwe', Kevin C. Diwe1, Irene A. Merenu1, \\ Chukwuma U. Okafor ${ }^{3}$, Chukwuyem Abejegah", Ugochukwu C. Madubueze5, \\ Emmanuel U. Ndukwu², Ikechi Ohale ${ }^{2}$
}

\author{
${ }^{1}$ Department of Community Medicine, Imo State University, Owerri, Nigeria \\ ${ }^{2}$ Department of Community Medicine, Imo State University Teaching Hospital, Orlu, Nigeria \\ ${ }^{3}$ Department of Psychiatry, University of Port Harcourt, Port Harcourt, Nigeria \\ ${ }^{4}$ Department of Community Medicine, Irrua Specialist Teaching Hospital, Irrua, Nigeria \\ ${ }^{5}$ Department of Community Medicine, Federal Teaching Hospital, Abakaliki, Nigeria \\ Email: *iwuchinedu@yahoo.com
}

How to cite this paper: Duru, C.B., Iwu, A.C., Uwakwe, K.A., Diwe, K.C., Merenu, I.A., Okafor, C.U., Abejegah, C., Madubueze, U.C., Ndukwu, E.U. and Ohale, I. (2017) Health Care Seeking Behaviour and Predictors of Combined Orthodox and Traditional Health Care Utilization among Households in Communities in Owerri, Imo State, Nigeria. Open Journal of Preventive Medicine, 7, 115-137.

https://doi.org/10.4236/ojpm.2017.77010

Received: June 23, 2017

Accepted: July 17, 2017

Published: July 20, 2017

Copyright $\odot 2017$ by authors and Scientific Research Publishing Inc. This work is licensed under the Creative Commons Attribution International License (CC BY 4.0).

http://creativecommons.org/licenses/by/4.0/ (c) (i) Open Access

\begin{abstract}
Background: Health care seeking behaviour is a complex, dynamic and multidimensional process that involves a sequence of remedial actions that are influenced by the interaction between the individual, household and community with the intention of addressing perceived ill health. Objective: To determine health care seeking attitude and behaviour and the predictors of combined orthodox and traditional health care use among households in communities in Owerri, Imo State. Nigeria. Methods: A cross sectional design that used a multistage random sampling technique to select 500 participants from households in two communities in Owerri, Imo State. Data was collected using a pretested, semi structured questionnaire. Descriptive analyses were done with frequencies and summary statistics. Chi square statistics were computed to determine significant relationships and binary logistic regression was used to determine predictors of combined use. $\mathrm{P}$ was set at 0.05 significance level. Results: The results revealed that, while just more than half of the respondents (56.4\%) had a moderate to good level of overall knowledge of health care, almost all of the respondents (96.2\%) also had a moderate to good level of overall positive attitude towards seeking health care; with less than one third (29.4\%) using combined orthodox and traditional health care treatments. It further revealed that, respondents who were female, traders and from households of polygamous families were significantly more likely to use
\end{abstract}


combined orthodox and traditional health care treatments $(\mathrm{p}<0.05)$ while those with a tertiary level of education, from households with a professional as head, having private water closet toilets and earning a monthly income of more than 50,000 Naira (\$140) were significantly less likely to use combined orthodox and traditional health care treatments $(\mathrm{p}<0.05)$. Conclusion: There is a need to be more sensitive to the realities of the combined use of orthodox and traditional treatments, as its use will be difficult to prevent because this behaviour is rooted in the traditional and cultural belief system of our societies.

\section{Keywords}

Health Seeking Behaviour, Combined Use, Orthodox and Traditional Treatments, Nigeria

\section{Introduction}

Health care seeking behaviour which is a sequence of remedial actions to address perceived ill health, is a complex, dynamic and multidimensional process that is not only influenced by the individual alone but by a broader interaction between the individual, household and community within the constraints of existing factors such as affordability, availability and accessibility [1] [2] [3].

In seeking health care, people's behaviour differ in relation to the number and type of health care services sought, which is influenced by the nature of the disease and who is experiencing it within the context of what they believe is the causation; and also, when it comes down to individual choices, people with care options will seek the care that perceivably meets their quality, convenience and cost [1].

Health care behaviour involves a combination of different responses such as seeking traditional care, spiritual care, drug store services, private and public orthodox care which differ over time, opportunity and circumstance in terms of the type of care individuals seek for themselves and members of their family [1]. This behaviour of serial or simultaneous engagements with different health care services are probably due to the belief that, one of the services may provide answers as to the cause of the disease or provide some form of relief or cure [4].

In Nigeria, the practice of home treatment with drugs which could be herbal or, and orthodox medicines bought without prescription from drug stores appear to be a significant health seeking behaviour, as observed in a Nigerian study, were most of the mothers within the first 24 hours of the child's illness gave them drugs at home [5].

In spite of the fact that, there is widespread popularity of modern health care services especially the private health services which includes both formal and informal drug stores; the traditional and religious health services are still commonly used and according to World Health Organization, at least $80 \%$ of people 
in Africa have used traditional health service at one point or the other in their everyday lives [1] [6].

The practice of traditional health services involves the use of herbs, spiritual intervention and local practices which are occasionally based on superstition [6] [7]. Herbs are natural and as such, its use is believed to be safe, but due to the potential for undesirable interactions with orthodox standardized medicines, the inappropriate combined use, can produce harmful effects [6].

It has been suggested that due to the different perceptions of the nature of an illness, individuals and families either seek traditional health care treatments first, prior to orthodox health care treatments or vice versa, depending on the perceived degree of its potential effectiveness with respect to the different aspects of the illness; and also, the level of satisfaction received during their first treatment contact. However, this implies that both treatments are used concomitant during the course of the same illness, with traditional and orthodox health care treatments being viewed as complimentary and not as alternative treatments [1] [8].

A study in Botswana, found that $95 \%$ of patients' first point of care was an orthodox health facility after which, $47 \%$ of these patients subsequently visited a traditional health service [9]. Similarly, a Kenyan study also observed that, the traditional health care treatments coexisted with, and complemented the orthodox health care treatments [7]. Although, the orthodox health care treatments were preferred, the traditional health care treatments were still frequently consulted, especially when the diseases were perceived to be of a supernatural nature, which they attribute as the cause, for whenever treatment with orthodox health care interventions fail [7].

It is obvious that people, due to a variety of reasons within a variety of contexts, are using traditional health care treatments and probably, increasingly combining them with orthodox health care treatments as observed by their movement back and forth between health services rather than receiving care from one care point [10]. This could potentially have significant effects on health; and therefore, it is important to recognize this reality of health seeking behaviour [11]. In Nigeria, the use of combined orthodox and traditional health care treatments appear to be significant, as prevalence rates of $31 \%$, $61.4 \%$ and $63.7 \%$ respectively have been reported in different studies [12] [13] [14].

The complex nature of health seeking behaviour especially in taking a decision towards a particular health care service is further emphasized by the fact that, educating and providing knowledge alone, is not sufficient to influence this behaviour; as other factors are required such as, the individual attitude which contributes to making the individual purposive and decisive; and also the household and the community that makes the individual interactive and dynamic [11]. Furthermore, socioeconomic factors such as sex, age, status, nature of illness, access and perceived quality of services have also been reported to influence the 
individual health decisions [11] [14]. However, health care generally, and especially for the rural and urban poor cannot be effectively provided, unless there is a basic understanding of their individual and environmental characteristics, health practices and also, their value and belief system which is embodied in their attitudes towards seeking health care [15].

Thus, this study attempts to assess the health seeking behaviour and attitude, the socio-demographic and household factors that influence health seeking behaviour with respect to the use of combined orthodox and traditional health care treatments among households in communities in Owerri, Imo State, Nigeria.

\section{Methodology}

\subsection{Study Area}

The study was conducted in two Local Government Areas in Owerri city in Imo State, South East, Nigeria. By the 2006 census, with a State annual growth rate of $3.2 \%$, Owerri municipal LGA had a total population of 125,337 (60,882 males and 64,455 females) and occupies an area of 58.5 square kilometers with a population density of about 2143 persons per square kilometer. Also Owerri North LGA had a total population of 176,334 (87,094 males and 89,240 females) and occupies an area of 200 square kilometers with a population density of about 882 persons per square kilometer [16].

\subsection{Study Population/Study Design/Selection Criteria}

The study population comprised male and female adults within households in communities in Owerri city, Imo State. The study was a descriptive cross sectional type. Any individual above 18 years old who had lived in the study area for at least one year was selected and interviewed.

\subsection{Sample Size Estimation}

The minimum sample size was calculated using the Cochrane formula [17]

$$
n=\frac{Z^{2} p q}{d^{2}}
$$

When $n=$ minimum sample size, $Z=$ Standard normal deviate corresponding to $5 \%$ significance level, $p=$ proportion of the target population that combined orthodox and traditional treatment in a previous study (63.7\%) [14], $q=1-p$ ( $1-0.64=0.36), d=$ tolerable error of margin set at $0.05, Z=1.96$. Applying the formula above, a sample size of 500 participants was used in this study to adjust for incomplete and non-response rate.

\subsection{Sampling Technique}

The sampling technique used to select the participants for this study was the multistage random sampling technique. The first stage involved the selection of 2 LGAs (Owerri municipal and Owerri North) from Owerri city which com- 
prise 3 LGAs, by simple random sampling using ballots. The second stage involved the selection of one community each (Umuodu and Egbu respectively) from Owerri municipal and Owerri North LGAs using simple random sampling by balloting. The third stage involved the selection of one participant from the individual households in the communities. In each community, a prominent location was identified and moving in a particular direction, each consecutive household was enrolled until 250 households were selected from each community. If there were more than one adult present in any household, balloting was done to select and enroll the eligible adult after an informed consent. Any household without an adult present after two repeat visits or had only one adult present, who had not lived in the area for at least one year was skipped.

\subsection{Data Collection and Analysis}

Data was collected within a three month period from January to March 2016 using a pretested, semi structured, self and interviewer administered questionnaire. The questionnaire was developed by the researchers and pretested in another LGA, outside the study area. The content validity was established qualitatively using a panel of four experts that assessed each question against the intended construct. The questionnaire comprised 4 sections; section one: the socio-demographic and household characteristics; section two: the knowledge of health care; section three: attitude towards seeking health care and section four: use of health care services.

The level of knowledge of health care was determined by scoring the questions that assessed knowledge. For a single response question, an appropriate answer was scored 2; an inappropriate answer was scored 0 . For a multiple response question, up to 2 appropriate answers scored 1, 3 to 5 appropriate answers scored 3 and greater than 5 appropriate answers scored 5. In assessing the level of attitude towards seeking health care, a Likert scale was used. For a positive question, a response from strongly agree to strongly disagree, a score from 5 to 1 was allocated accordingly and for a negative question, a response of "strongly disagree" to "strongly agree", a score from 5 to 1 was allocated accordingly. The aggregate scores for each respondent according to the level of knowledge and attitude towards seeking health care were translated to a percentage and assessed against a scale of less than $60 \%$ for poor, $60 \%-80 \%$ for moderate and greater than $80 \%$ for good. Data was cleaned, validated manually and analyzed using Software Package for Social Sciences (IBM-SPSS) version 22. Descriptive statistics (frequency tables and summary indices) were generated. Chi Square was used to test association between socio-demographic and household characteristics; and the combined orthodox and traditional health care use. Statistically significant associations were included in the regression model and binary logistic regression was applied to determine the predictors of combined use. P value of $\leq$ 0.05 was considered significant. 


\subsection{Study Limitation}

Accessibility and consequently, the administration of the questionnaire to most of the parents of households during the day was a limitation, as a significant proportion leave the house early in the morning and return late in the evening from their respective occupations.

\subsection{Ethical Considerations}

Ethical approval was obtained from the Ethics Committee of Imo State University Teaching Hospital Orlu. Informed consents were obtained from the participants. All authors hereby declare that the study was performed in accordance with the ethical standards laid down in the 1964 Declaration of Helsinki.

\section{Results}

Five hundred questionnaires were administered but 456 were completely and correctly filled with a response rate of $91.2 \%$.

\subsection{Socio-Demographic Characteristics of Respondents}

The mean age of the respondents was $29 \pm 8.2$ years with majority of them being female (63.6\%), students (55.3\%), currently single (61.6\%) and having a tertiary education (77.6\%). Close to half of the respondents were of the Christian catholic faith $(47.4 \%)$ and $44.7 \%$ of the respondents were adult children living with their parents in the household (Table 1).

\subsection{Household Characteristics of Respondents}

Most of the households heads were males (86.8\%) and living in a household that is of a monogamous family setting (82.2\%), with a majority of the household heads having attained a tertiary level of education (66.2\%) and were either civil servants or traders (73.4\%). Majority of the respondents' were living in households comprising 5 - 8 members (55.5\%) which included up to 4 children (53.0\%). Though, close to half of the respondents (44.7\%) were unable to give an estimate of their household monthly income, a majority of the respondents were living in houses owned by them or their families (58.6\%) with most of them having their water supply from private boreholes $(75.9 \%)$ and using private water closet toilet facilities (81.1\%) (Table 2).

\subsection{Knowledge of Health Care of Respondents}

Majority of the respondents were aware of what appropriate health care is (69.5\%) and their source of information about appropriate health care, was from the television (58.0\%) and radio (52.9\%). Though a majority of the respondents indicated that the source of receiving health care treatment was from private (77.2\%) and public hospitals (72.6\%), about $11 \%-20 \%$ indicated that the sources of receiving health care treatment were from spiritual healers (11.7\%), Christian churches (14.9\%), faith-based institutions (20.2\%) and traditional 
Table 1. Sociodemographic characteristics of respondents.

\begin{tabular}{ccc}
\hline Variable & Category & Frequency $(\%) \mathrm{n}=456$ \\
\hline Age (years) & $20-29$ & $297(65.1)$ \\
Mean age $(29.0 \pm 8.2)$ & $30-39$ & $81(17.8)$ \\
Gender & $>40$ & $78(17.1)$ \\
& Male & $166(36.4)$ \\
Religion & Female & $290(63.6)$ \\
& Catholic & $216(47.4)$ \\
& Pentecostal & $181(39.7)$ \\
Marital status & Orthodox & $33(7.2)$ \\
& Others & $26(5.7)$ \\
& Single & $281(61.6)$ \\
Household status & Married & $142(31.1)$ \\
& Others & $33(7.2)$ \\
& Child & $204(44.7)$ \\
& Father & $161(35.3)$ \\
& Mother & $86(18.9)$ \\
Educational level & Relative & $5(1.1)$ \\
& Tertiary & $354(77.6)$ \\
& Secondary & $70(15.4)$ \\
& Primary & $14(3.1)$ \\
& None & $18(3.9)$ \\
& Students & $252(55.3)$ \\
& Traders & $65(14.3)$ \\
& Pril servants & $57(12.5)$ \\
& Others & $53(11.6)$ \\
& & $29(6.4)$ \\
\hline
\end{tabular}

1-traditional, Islam. 2-living with partner, separated, divorce, widow. 3-artisan, housewife.

healers (20.6\%). Most of the respondents were aware of a health facility in their community (89.5\%) and the type most known to them was a public hospital (85.3\%); though, about $26.5 \%$ knew of the traditional healing homes in their community. Most of the respondents were aware of the different types of illnesses that can occur around them (91.9\%), while most reported knowing that malaria (91.2\%) can occur around them, less than 3.3\% reported knowing HIV as an illness that can occur around them with majority of the respondents reporting death $(74.5 \%)$ as a known consequence of poorly treated illness or disease (Table 3).

Furthermore, the more than half of the respondents (56.4\%) had a moderate to good level of health care knowledge (Figure 1).

\subsection{Attitude of Respondents towards Seeking Health Care}

Most of the respondents strongly agreed that it is important to seek health care early when sick (82.4\%). Close to half of the respondents (45.6\%) were of the opinion that, what is important is seeking health care and not where you seek care first. Majority of the respondents were of the opinion that it is important to see a medical doctor first when sick $(80.9 \%)$ and that, modern drugs have been researched more than traditional drugs and therefore should be only used when 
Table 2. Household characteristics of respondents.

\begin{tabular}{|c|c|c|}
\hline Variable & Category & Frequency $(\%) \mathrm{n}=456$ \\
\hline \multirow{2}{*}{ Head of Household } & Male & $396(86.8)$ \\
\hline & Female & $60(13.2)$ \\
\hline \multirow{4}{*}{ Occupation of Household Head } & Civil servants & $178(39.0)$ \\
\hline & Traders & $157(34.4)$ \\
\hline & Professionals & $86(18.9)$ \\
\hline & Others ${ }^{4}$ & $35(7.7)$ \\
\hline \multirow{4}{*}{ Educational level of Household Head } & Tertiary & $302(66.2)$ \\
\hline & Secondary & $99(21.7)$ \\
\hline & Primary & $31(6.8)$ \\
\hline & None & $24(5.3)$ \\
\hline \multirow{2}{*}{ Household family type } & Monogamous & $375(82.2)$ \\
\hline & Polygamous & $81(17.8)$ \\
\hline \multirow{3}{*}{$\begin{array}{c}\text { Household size } \\
\text { Mean size }(5.7 \pm 3.6)\end{array}$} & $1-4$ & $119(26.1)$ \\
\hline & $5-8$ & $253(55.5)$ \\
\hline & $>8$ & $84(18.4)$ \\
\hline \multirow{4}{*}{$\begin{array}{l}\text { Number of children per household } \\
\text { Mean number }(4.3 \pm 2.3)\end{array}$} & 0 & $33(7.2)$ \\
\hline & $1-4$ & $209(45.8)$ \\
\hline & $5-8$ & $187(41.0)$ \\
\hline & $>8$ & $27(5.9)$ \\
\hline \multirow{2}{*}{ House ownership } & Owner & $267(58.6)$ \\
\hline & Tenant & $189(41.4)$ \\
\hline \multirow{3}{*}{ Source of water supply } & Private Borehole & $346(75.9)$ \\
\hline & Public works & $78(17.1)$ \\
\hline & Others ${ }^{5}$ & $32(7.0)$ \\
\hline \multirow{4}{*}{ Toilet facilities } & Private water closet & $370(81.1)$ \\
\hline & Shared water closet & $57(12.5)$ \\
\hline & Pit latrine & $20(4.4)$ \\
\hline & Open defecation & $9(2.0)$ \\
\hline \multirow{4}{*}{ Household Monthly Income (Naira) } & $<10,000$ & $23(5.0)$ \\
\hline & $10,000-50,000$ & $141(30.9)$ \\
\hline & $>50,000$ & $88(19.3)$ \\
\hline & Cannot estimate & $204(44.7)$ \\
\hline
\end{tabular}

4-artisan, student, housewife. 5-rainwater, shallow well, rivers, streams.

sick (69.5\%) with a majority of the respondents (61.8\%) having the opinion that traditional drugs can be very dangerous to health. Despite this, more than half of the respondents (56.5\%) were either in agreement or undecided about traditional drugs being more effective than modern drugs in treating most diseases. Close to one quarter of the respondents $(24.4 \%)$ were either in agreement or undecided about buying drugs from a chemist without a prescription. More than one third of the respondents (36.2\%) were either in agreement or undecided about receiving a prescription from a laboratory scientist in the absence of a doctor. Though, most of the respondents were of the opinion that, it is good to take medical advice from a trained health professional (88.2\%), close to one third of the respondents (31.1\%) were either in agreement or undecided about seeking health care from the church or spiritual healing homes when sick. Also, close to one third of the respondents $(30.2 \%)$ were either in agreement or undecided 
Table 3. Respondents' knowledge of health care.

\begin{tabular}{|c|c|c|}
\hline Variable & Category & Frequency $(\%)$ \\
\hline \multirow{2}{*}{ Awareness of what appropriate health care is? $(n=456)$} & Yes & $317(69.5)$ \\
\hline & No & $139(30.5)$ \\
\hline \multirow{11}{*}{$\begin{array}{l}\text { *Source of information of what appropriate health care } \\
\qquad \text { is }(\mathrm{n}=317)\end{array}$} & Television & $184(58.0)$ \\
\hline & Radio & $168(52.9)$ \\
\hline & Health care staff & $136(42.9)$ \\
\hline & School/lectures & $127(40.0)$ \\
\hline & Friends/family & $105(33.1)$ \\
\hline & Newspaper/magazine & $98(31.0)$ \\
\hline & Books & $82(25.9)$ \\
\hline & Poster/billboard & $71(22.5)$ \\
\hline & Church & $57(18.0)$ \\
\hline & Markets/town crier & $45(14.2)$ \\
\hline & Others & $21(6.6)$ \\
\hline \multirow{8}{*}{${ }^{*}$ Sources of appropriate health care treatment $(\mathrm{n}=456)$} & Private hospital & $352(77.2)$ \\
\hline & Public hospital & $331(72.6)$ \\
\hline & Pharmacy/chemist & $212(46.5)$ \\
\hline & Self-medication & $156(34.2)$ \\
\hline & Traditional healers & $94(20.6)$ \\
\hline & Faith based institutions & $92(20.2)$ \\
\hline & Christian Churches & $68(14.9)$ \\
\hline & Spiritual healers & $53(11.7)$ \\
\hline \multirow{2}{*}{$\begin{array}{l}\text { Awareness of health facility in community? } \\
\qquad(\mathrm{n}=456)\end{array}$} & Yes & $408(89.5)$ \\
\hline & No & $48(10.5)$ \\
\hline \multirow{6}{*}{$\begin{array}{l}{ }^{*} \text { What are the types of health facility in the } \\
\text { community? }(\mathrm{n}=408)\end{array}$} & Public hospital & $348(85.3)$ \\
\hline & Private hospital & $294(72.1)$ \\
\hline & Pharmacy/chemist & $221(54.2)$ \\
\hline & Traditional healing homes & $108(26.5)$ \\
\hline & Churches & $74(18.1)$ \\
\hline & Spiritual healing homes & $64(15.7)$ \\
\hline \multirow{2}{*}{$\begin{array}{l}\text { Awareness of the types of illnesses/diseases that can } \\
\qquad \text { occur around you? }(\mathrm{n}=456)\end{array}$} & Yes & $419(91.9)$ \\
\hline & No & $37(8.1)$ \\
\hline \multirow{14}{*}{$\begin{array}{l}{ }^{\star} \text { What are the different types of illnesses that can occur } \\
\text { around you? }(\mathrm{n}=419)\end{array}$} & Malaria & $382(91.2)$ \\
\hline & Typhoid fever & $332(79.2)$ \\
\hline & Asthma & $273(65.2)$ \\
\hline & Diabetes & $271(64.2)$ \\
\hline & Hypertension & $266(63.5)$ \\
\hline & Ebola & $239(57.0)$ \\
\hline & Hepatitis & $237(56.6)$ \\
\hline & Cancers & $233(55.8)$ \\
\hline & Tuberculosis & $217(51.8)$ \\
\hline & Skin disease & $217(51.8)$ \\
\hline & Diarrhoea & $214(51.1)$ \\
\hline & Pneumonia & $211(50.4)$ \\
\hline & Worm infestation & $202(48.2)$ \\
\hline & Lassa fever & $187(44.6)$ \\
\hline \multirow{7}{*}{$\begin{array}{l}{ }^{*} \text { What are the consequences of poorly treated } \\
\text { illness/disease? }(\mathrm{n}=419)\end{array}$} & Others $^{1}$ & $14(3.3)$ \\
\hline & Death & $312(74.5)$ \\
\hline & Inability to perform tasks & $243(58.0)$ \\
\hline & Fainting spells & $219(52.3)$ \\
\hline & Permanent disability & $200(47.7)$ \\
\hline & Convulsion & $162(38.7)$ \\
\hline & Coma & $148(35.3)$ \\
\hline
\end{tabular}

${ }^{*}$ Multiple responses. 1-HIV, ulcer. 


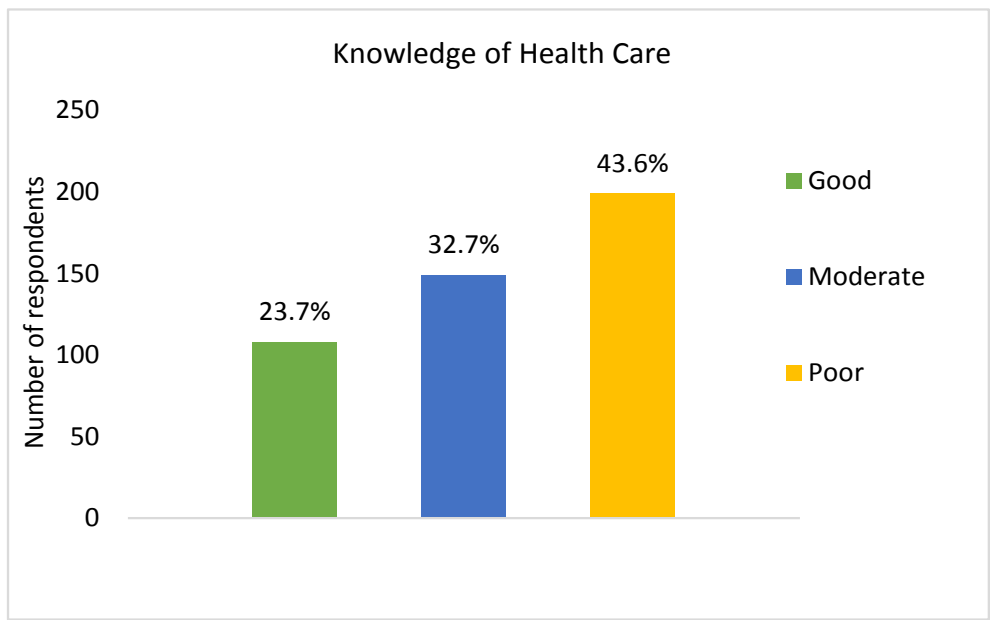

Figure 1. Level of health care knowledge of respondents.

about the importance of not going for medical check-ups except when feeling sick. While most of the respondents (95.3\%) were of the opinion that eating proper foods improves health, close to one third of the respondents (30.9\%) were either in agreement or undecided about stress at work being a substitute for regular exercise (Table 4).

Generally, most of the respondents (96.2\%) had a moderate to good level of positive attitude towards seeking health care (Figure 2).

\subsection{Use of Health Care Services by Respondents}

Most of the respondents reported that, they have been sick before (95.4\%) with a majority staying up to 3 days before seeking treatment (69.7\%) and about 13.6\% seeking treatment only when the illness becomes serious. Most of the respondents preferred using modern health care services (94.9\%) with majority (63.2\%) attributing effective treatment as the reason for their preference and those that preferred using traditional, all (100\%) attributed culture and belief as the reason for their preference.

Close to half of the respondents when ill (48.1\%), either self-medicate themselves first with home treatments or with drugs bought without a prescription from the pharmacy or chemist (formal and informal drug stores). The main reasons given for their health seeking choice of first treatment were prompt care (36.6\%) personal attention (32.9\%), effective treatment (26.4\%) and proximity to home (24.1\%). Close to one third of the respondents (29.4\%) combined orthodox and traditional health care treatments when sick and the major reason for use as reported by users is that its effective (58.6\%) (Table 5).

Furthermore, among those who do not combine orthodox and traditional care when sick, most of them use only orthodox treatment when sick (93.2\%).

\subsection{Socio-Demographic Factors Associated with Combined Use of Modern and Traditional Health Care Treatment}

The following socio-demographic factors were significantly associated with the 
Table 4. Respondents' attitude towards seeking health care.

\begin{tabular}{|c|c|c|}
\hline Variable & Category & Frequency $(\%) \mathrm{n}=456$ \\
\hline \multirow{5}{*}{$\begin{array}{l}\text { Do you think that when sick, it is important to } \\
\text { seek health care early? }\end{array}$} & Strongly agree & $375(82.4)$ \\
\hline & Agree & $70(15.4)$ \\
\hline & Undecided & $3(0.7)$ \\
\hline & Disagree & $5(1.1)$ \\
\hline & Strongly disagree & $2(0.4)$ \\
\hline \multirow{5}{*}{$\begin{array}{l}\text { Do you think that, what is important is seeking } \\
\text { health care and not where you seek care first? }\end{array}$} & Strongly agree & $95(20.8)$ \\
\hline & Agree & $113(24.8)$ \\
\hline & Undecided & $43(9.4)$ \\
\hline & Disagree & $130(28.5)$ \\
\hline & Strongly disagree & $75(16.4)$ \\
\hline \multirow{5}{*}{$\begin{array}{l}\text { Do you think, it is important to see a medical } \\
\text { doctor first, when sick? }\end{array}$} & Strongly agree & $195(42.8)$ \\
\hline & Agree & $174(38.1)$ \\
\hline & Undecided & $34(7.5)$ \\
\hline & Disagree & $44(9.6)$ \\
\hline & Strongly disagree & $9(2.0)$ \\
\hline \multirow{5}{*}{$\begin{array}{l}\text { Do you think that, modern drugs have been } \\
\text { researched more than traditional drugs and } \\
\text { therefore should be only used when sick? }\end{array}$} & Strongly agree & $157(34.4)$ \\
\hline & Agree & $160(35.1)$ \\
\hline & Undecided & $85(18.6)$ \\
\hline & Disagree & $41(19.0)$ \\
\hline & Strongly disagree & $13(2.9)$ \\
\hline \multirow{5}{*}{$\begin{array}{c}\text { Do you think that traditional drugs are more } \\
\text { effective than modern drugs in treating most } \\
\text { diseases? }\end{array}$} & Strongly agree & $56(12.3)$ \\
\hline & Agree & $68(15.0)$ \\
\hline & Undecided & $133(29.2)$ \\
\hline & Disagree & $145(31.8)$ \\
\hline & Strongly disagree & $54(11.8)$ \\
\hline \multirow{5}{*}{$\begin{array}{l}\text { Do you think that traditional drugs can be very } \\
\text { dangerous to health? }\end{array}$} & Strongly agree & $125(27.4)$ \\
\hline & Agree & $157(34.4)$ \\
\hline & Undecided & $77(16.9)$ \\
\hline & Disagree & $72(15.8)$ \\
\hline & Strongly disagree & $25(5.5)$ \\
\hline \multirow{5}{*}{$\begin{array}{l}\text { Do you think that it is okay to buy drugs from } \\
\text { the chemist without a prescription? }\end{array}$} & Strongly agree & $20(4.4)$ \\
\hline & Agree & $29(6.4)$ \\
\hline & Undecided & $62(13.6)$ \\
\hline & Disagree & $221(48.5)$ \\
\hline & Strongly disagree & $124(27.2)$ \\
\hline \multirow{5}{*}{$\begin{array}{c}\text { Do you think that without a doctor, a } \\
\text { prescription from a laboratory scientist is } \\
\text { okay? }\end{array}$} & Strongly agree & $26(5.7)$ \\
\hline & Agree & $66(14.5)$ \\
\hline & Undecided & $73(16.0)$ \\
\hline & Disagree & $198(43.4)$ \\
\hline & Strongly disagree & $93(20.4)$ \\
\hline \multirow{5}{*}{$\begin{array}{l}\text { Do you think it is good to take medical advice } \\
\text { from a trained health professional? }\end{array}$} & Strongly agree & $269(59.0)$ \\
\hline & Agree & $133(29.2)$ \\
\hline & Undecided & $16(3.5)$ \\
\hline & Disagree & $24(5.3)$ \\
\hline & Strongly disagree & $14(3.1)$ \\
\hline \multirow{5}{*}{$\begin{array}{c}\text { Do you think that the best thing to do when } \\
\text { sick, is to go to church or spiritual healing } \\
\text { homes? }\end{array}$} & Strongly agree & $17(3.7)$ \\
\hline & Agree & $38(8.3)$ \\
\hline & Undecided & $87(19.1)$ \\
\hline & Disagree & $166(36.4)$ \\
\hline & Strongly disagree & $148(32.5)$ \\
\hline
\end{tabular}




\section{Continued}

\begin{tabular}{ccc}
\hline & Strongly agree & $23(5.0)$ \\
Do you think it is not important to go for & Agree & $68(14.9)$ \\
medical check-ups except when feeling sick? & Undecided & $47(10.3)$ \\
& Disagree & $206(45.2)$ \\
& Strongly disagree & $112(24.6)$ \\
Do you think eating proper foods improves & Strongly agree & $366(80.3)$ \\
health? & Agree & $67(15.0)$ \\
& Undecided & $13(2.9)$ \\
& Disagree & $1(0.2)$ \\
Do you think that stress at work is a substitute & Strongly disagree & $9(2.0)$ \\
for regular exercise? & Strongly agree & $28(6.1)$ \\
& Agree & $47(10.3)$ \\
& Undecided & $66(14.5)$ \\
& Disagree & $195(42.8)$ \\
& Strongly disagree & $120(26.3)$ \\
\hline
\end{tabular}

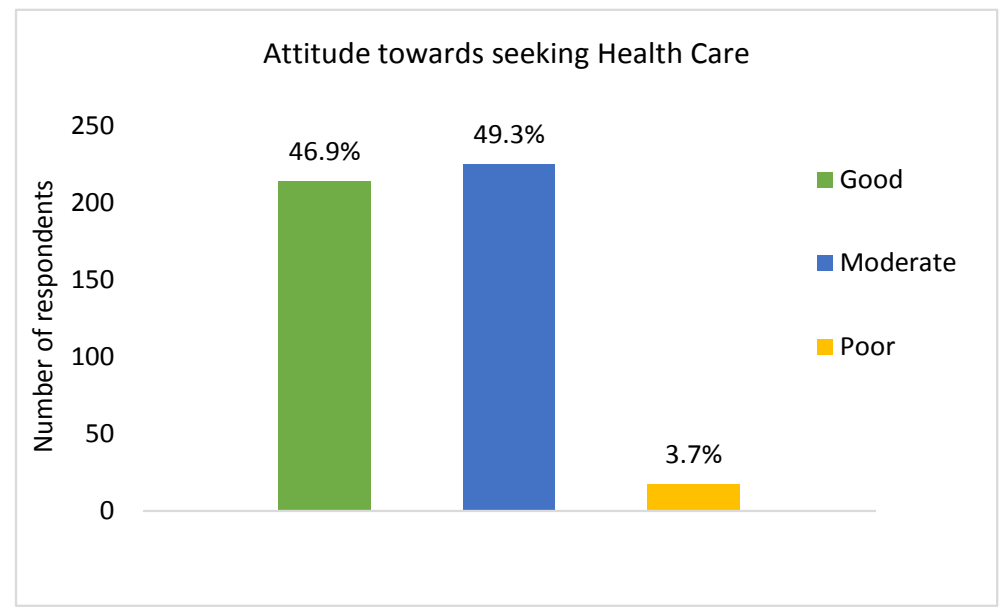

Figure 2. Level of positive attitude towards seeking health care.

use of combined orthodox and traditional health care treatments; educational level of the respondents $(\mathrm{p}<0.0001)$ and occupation of the respondents $(\mathrm{p}=$ 0.020 ). On the other hand; age, gender, religion, marital status and status in the household were not significantly associated with combined use $(\mathrm{p}>0.05)$ (Table $6)$.

\subsection{Household Factors Associated with Combined Use of Orthodox and Traditional Health Care Treatment}

The following household factors were significantly associated with the use of combined orthodox and traditional health care treatments; Gender of the household head $(\mathrm{p}=0.010)$, Occupation of the household head $(\mathrm{p}=0.001)$, Educational level of the household head $(\mathrm{p}=0.001)$, Household family type $(\mathrm{p}=$ 0.001), Type of household toilet facilities ( $\mathrm{p}<0.0001)$ and Household Monthly Income ( $p=0.008)$. On the other hand; Household size, Number of children per household, House ownership and Sources of water supply were not significantly associated with use $(\mathrm{p}>0.05)$ (Table 7). 
Table 5. Respondents' use of health care services.

\begin{tabular}{|c|c|c|}
\hline Variable & Category & Frequency $(\%)$ \\
\hline \multirow{2}{*}{ Have you been sick before? $(\mathrm{n}=456)$} & Yes & $435(95.4)$ \\
\hline & No & $21(4.6)$ \\
\hline \multirow{5}{*}{$\begin{array}{l}\text { Usual duration of any illness before seeking } \\
\text { treatment }(\mathrm{n}=435)\end{array}$} & Immediate & $146(33.6)$ \\
\hline & $1-3$ days & $157(36.1)$ \\
\hline & $>3$ days & $55(12.6)$ \\
\hline & When it becomes serious & $59(13.6)$ \\
\hline & Do not seek treatment & $18(4.1)$ \\
\hline \multirow{2}{*}{$\begin{array}{l}\text { What is your preferred health care use } \\
\qquad(\mathrm{n}=435)\end{array}$} & Orthodox health care & $413(94.9)$ \\
\hline & Traditional health care & $22(5.1)$ \\
\hline \multirow{5}{*}{$\begin{array}{l}{ }^{*} \text { If orthodox, what are your reasons for } \\
\text { preference }(\mathrm{n}=413)\end{array}$} & Effective treatment & $261(63.2)$ \\
\hline & Expert management & 194(47.0) \\
\hline & Complication prevention & $142(34.4)$ \\
\hline & Prompt treatment & $80(19.4)$ \\
\hline & Prompt referral & $54(13.1)$ \\
\hline \multirow{7}{*}{$\begin{array}{l}\text { *If traditional, what are your reasons for } \\
\text { preference }(\mathrm{n}=22)\end{array}$} & Culture/belief & $22(100)$ \\
\hline & Low cost & 13(59.1) \\
\hline & Proximity to home & $12(54.5)$ \\
\hline & Receives support & $8(36.4)$ \\
\hline & Receives attention & $8(36.4)$ \\
\hline & Home visits & $6(27.3)$ \\
\hline & Attitude of hospital staff & $5(22.7)$ \\
\hline \multirow{7}{*}{$\begin{array}{l}\text { Where do you seek treatment first? } \\
\qquad(\mathrm{n}=435)\end{array}$} & Private hospital & $132(30.3)$ \\
\hline & Home treatments & $129(29.7)$ \\
\hline & Public hospital & $96(22.1)$ \\
\hline & Pharmacy/chemist & $80(18.4)$ \\
\hline & Faith based & $16(3.7)$ \\
\hline & Traditional healers & $9(2.1)$ \\
\hline & Churches & $3(0.7)$ \\
\hline \multirow{7}{*}{$\begin{array}{l}\text { *Why do you seek treatment first from the } \\
\text { place you do? }(\mathrm{n}=435)\end{array}$} & Receive care fast & $159(36.6)$ \\
\hline & Personal attention & $143(32.9)$ \\
\hline & Effective treatment & $115(26.4)$ \\
\hline & Proximity to home & $105(24.1)$ \\
\hline & Provide support & $57(13.1)$ \\
\hline & Care is inexpensive & $35(8.0)$ \\
\hline & Cultural belief & $34(7.8)$ \\
\hline \multirow{2}{*}{$\begin{array}{l}\text { When sick, do you use combined orthodox } \\
\text { and traditional health care treatments? } \\
\qquad(\mathrm{n}=435)\end{array}$} & Yes & $128(29.4)$ \\
\hline & No & $307(70.6)$ \\
\hline \multirow{2}{*}{$\begin{array}{l}\text { If you do not, what treatments do you use? } \\
\qquad(\mathrm{n}=307)\end{array}$} & orthodox only & $286(93.2)$ \\
\hline & Traditional only & $21(6.8)$ \\
\hline \multirow{4}{*}{$\begin{array}{l}{ }^{\star} \text { Why do you use combined modern and } \\
\text { traditional health care treatments? }(\mathrm{n}=128)\end{array}$} & Treatment is effective & $75(58.6)$ \\
\hline & Recommended by family and friends & $35(27.3)$ \\
\hline & A better feeling & $32(25.0)$ \\
\hline & Cultural belief & $16(12.5)$ \\
\hline
\end{tabular}

${ }^{*}$ Multiple response.

\subsection{Predictors of Combined Use of Orthodox and Traditional Health Care Treatment}

Respondents with a tertiary level of education were significantly less likely to use combined orthodox and traditional health care treatments when compared to 
Table 6. Socio-demographic factors associated with combined use of orthodox and traditional health care treatment.

\begin{tabular}{|c|c|c|c|c|c|c|}
\hline \multicolumn{7}{|c|}{ Combined Modern and Traditional Health Care Treatment } \\
\hline Variable & USE (\%) & NON-USE (\%) & Total (\%) & $\chi^{2}$ & df & p-value \\
\hline \multicolumn{7}{|l|}{ Age (yrs) } \\
\hline $20-29$ & $80(29.0)$ & $196(71.0)$ & $276(100)$ & 0.80 & 2 & 0.671 \\
\hline $30-39$ & $22(27.2)$ & $59(72.8)$ & $81(100)$ & & & \\
\hline$\geq 40$ & $26(33.3)$ & $52(66.7)$ & $78(100)$ & & & \\
\hline Total & $128(29.4)$ & $307(70.6)$ & $435(100)$ & & & \\
\hline \multicolumn{7}{|l|}{ Gender } \\
\hline Male & $54(34.2)$ & $104(65.8)$ & $158(100)$ & 2.70 & 1 & 0.100 \\
\hline Female & $74(26.7)$ & $203(73.3)$ & $277(100)$ & & & \\
\hline Total & $128(29.4)$ & $307(70.6)$ & $435(100)$ & & & \\
\hline \multicolumn{7}{|l|}{ Religion } \\
\hline Catholic & $54(26.0)$ & $154(74.0)$ & $208(100)$ & 3.81 & 3 & 0.283 \\
\hline Pentecostal & $56(30.8)$ & $126(69.2)$ & $182(100)$ & & & \\
\hline Orthodox & $13(39.4)$ & $20(60.6)$ & $33(100)$ & & & \\
\hline Others & $5(41.7)$ & $7(58.3)$ & $12(100)$ & & & \\
\hline Total & $128(29.4)$ & $307(70.6)$ & $435(100)$ & & & \\
\hline \multicolumn{7}{|l|}{ Marital Status } \\
\hline Single & $72(26.1)$ & 204(73.9) & $276(100)$ & 5.11 & 2 & 0.078 \\
\hline Married & $47(33.8)$ & $92(66.2)$ & $139(100)$ & & & \\
\hline Others & $9(45.0)$ & $11(55.0)$ & $20(100)$ & & & \\
\hline Total & $128(29.4)$ & $307(70.6)$ & $435(100)$ & & & \\
\hline \multicolumn{7}{|c|}{ Position in household } \\
\hline Child & $57(29.1)$ & $139(70.9)$ & $196(100)$ & $3.62 \mathrm{a}$ & 3 & 0.305 \\
\hline Father & $54(33.5)$ & $107(66.5)$ & $161(100)$ & & & \\
\hline Mother & $16(21.9)$ & $57(78.1)$ & $73(100)$ & & & \\
\hline Relative & $1(20.0)$ & $4(80.0)$ & $5(100)$ & & & \\
\hline Total & $128(29.4)$ & $307(70.6)$ & $435(100)$ & & & \\
\hline \multicolumn{7}{|c|}{ Educational level } \\
\hline Tertiary & $84(24.1)$ & $265(75.9)$ & $349(100)$ & $23.23 a$ & 3 & $0.000^{*}$ \\
\hline Secondary & $36(50.0)$ & $36(50.0)$ & $72(100)$ & & & \\
\hline Primary & $3(50.0)$ & $3(50.0)$ & $6(100)$ & & & \\
\hline None & $5(62.5)$ & $3(37.5)$ & $8(100)$ & & & \\
\hline Total & $128(29.4)$ & $307(70.6)$ & $435(100)$ & & & \\
\hline \multicolumn{7}{|l|}{ Occupation } \\
\hline Student & $69(28.2)$ & $176(71.8)$ & $245(100)$ & 11.66 & 4 & $0.020^{*}$ \\
\hline Trader & $25(44.6)$ & $31(55.4)$ & $56(100)$ & & & \\
\hline Civil servant & $14(24.6)$ & $43(75.4)$ & $57(100)$ & & & \\
\hline Professional & $10(18.9)$ & $43(81.1)$ & $53(100)$ & & & \\
\hline Others & $10(41.7)$ & $14(58.3)$ & $24(100)$ & & & \\
\hline Total & $128(29.4)$ & $307(70.6)$ & $435(100)$ & & & \\
\hline
\end{tabular}

*Significant a likelihood ratio.

those without an education (OR: 0.19; $0.045-0.813, \mathrm{p}=0.026$ ). Respondents that were traders were significantly more likely to use combined orthodox and traditional health care treatments when compared to those that were students (OR: $2.06 ; 1.134-3.733, \mathrm{p}=0.016$ ). Female respondents were significantly more likely to use combined orthodox and traditional health care treatments when compared to the male respondents (OR: 2.29; $1.207-4.332, \mathrm{p}=0.010$ ). Respondents where the household heads were professionals were significantly less likely 
Table 7. Household factors associated with combined use of modern and traditional treatment.

\begin{tabular}{|c|c|c|c|c|c|}
\hline \multicolumn{6}{|c|}{ Combined Modern and Traditional Health Care Treatment } \\
\hline Variable & USE (\%) & NON-USE (\%) & Total (\%) & $x^{2} d$ & df p-value \\
\hline \multicolumn{6}{|c|}{ Gender of Household Head } \\
\hline Male & $108(27.6)$ & $284(72.4)$ & $392(100)$ & 6.71 & $10.010^{*}$ \\
\hline Female & $20(46.5)$ & $23(53.5)$ & $43(100)$ & & \\
\hline Total & $128(29.4)$ & $307(70.6)$ & $435(100)$ & & \\
\hline \multicolumn{6}{|c|}{ Occupation of Household Head } \\
\hline Civil servant & $58(34.5)$ & $110(65.5)$ & $168(100)$ & 16.633 & $30.001^{*}$ \\
\hline Trader & $48(32.4)$ & $100(67.6)$ & $148(100)$ & & \\
\hline Professional & $10(11.6)$ & $76(88.4)$ & $86(100)$ & & \\
\hline Others & $12(36.4)$ & $21(63.6)$ & $33(100)$ & & \\
\hline Total & $128(29.4)$ & $307(70.6)$ & $435(100)$ & & \\
\hline \multicolumn{6}{|c|}{ Educational level of Household Head } \\
\hline Tertiary & $72(23.8)$ & $230(76.2)$ & $302(100)$ & 17.49 & $30.001^{*}$ \\
\hline Secondary & $43(43.4)$ & $56(56.6)$ & $99(100)$ & & \\
\hline Primary & $10(47.6)$ & $11(52.4)$ & $21(100)$ & & \\
\hline None & $3(23.1)$ & $10(76.9)$ & $13(100)$ & & \\
\hline Total & $128(29.4)$ & $307(70.6)$ & $435(100)$ & & \\
\hline \multicolumn{6}{|l|}{ Household family type } \\
\hline Monogamous & $97(26.4)$ & $271(73.6)$ & $368(100)$ & 10.82 & $10.001^{*}$ \\
\hline Polygamous & $31(46.3)$ & $36(53.7)$ & $67(100)$ & & \\
\hline Total & $128(29.4)$ & $307(70.6)$ & $435(100)$ & & \\
\hline \multicolumn{6}{|l|}{ Household size } \\
\hline $1-4$ & $37(33.3)$ & $74(66.7)$ & $111(100)$ & 1.12 & 20.570 \\
\hline $5-8$ & $68(28.3)$ & $172(71.7)$ & $240(100)$ & & \\
\hline$>8$ & $23(27.4)$ & $61(72.6)$ & $84(100)$ & & \\
\hline Total & $128(29.4)$ & $307(70.6)$ & $435(100)$ & & \\
\hline \multicolumn{6}{|c|}{ Number of children per household } \\
\hline 0 & $8(29.6)$ & $19(70.4)$ & $27(100)$ & 4.623 & 30.202 \\
\hline $1-4$ & $68(33.7)$ & $134(66.3)$ & $202(100)$ & & \\
\hline $5-8$ & $44(24.0)$ & $139(76.0)$ & $183(100)$ & & \\
\hline$>8$ & $8(34.8)$ & $15(65.2)$ & $23(100)$ & & \\
\hline Total & $128(29.4)$ & $307(70.6)$ & $435(100)$ & & \\
\hline \multicolumn{6}{|l|}{ House ownership } \\
\hline Owner & $77(29.1)$ & $188(70.9)$ & $265(100)$ & 0.04 & 10.833 \\
\hline Tenant & $51(30.0)$ & $119(70.0)$ & $170(100)$ & & \\
\hline Total & $128(29.4)$ & $307(70.6)$ & $435(100)$ & & \\
\hline \multicolumn{6}{|l|}{ Source of water supply } \\
\hline Private Borehole & $96(28.7)$ & $239(71.3)$ & $335(100)$ & 1.102 & 20.577 \\
\hline Public works & $20(29.4)$ & $48(70.6)$ & $68(100)$ & & \\
\hline Others & $12(37.5)$ & $20(62.5)$ & $32(100)$ & & \\
\hline Total & $128(29.4)$ & $307(70.6)$ & $435(100)$ & & \\
\hline \multicolumn{6}{|c|}{ Household toilet facilities } \\
\hline Private water closet & $90(24.3)$ & $280(75.7)$ & $370(100)$ & 43.613 & $30.000^{*}$ \\
\hline Shared water closet & $27(75.0)$ & $9(25.0)$ & $36(100)$ & & \\
\hline Pit latrine & $6(30.0)$ & $14(70.0)$ & $20(100)$ & & \\
\hline Open defecation & $5(55.6)$ & $4(44.4)$ & $9(100)$ & & \\
\hline Total & $128(29.4)$ & $307(70.6)$ & $435(100)$ & & \\
\hline \multicolumn{6}{|c|}{ Household Monthly Income (Naira) } \\
\hline$<10,000$ & $12(34.3)$ & $23(65.7)$ & $35(100)$ & 11.943 & $30.008^{*}$ \\
\hline $10,000-50,000$ & $42(37.8)$ & $69(62.2)$ & $111(100)$ & & \\
\hline$>50,000$ & $14(15.9)$ & $74(84.1)$ & $88(100)$ & & \\
\hline Cannot estimate & $60(29.9)$ & $141(70.1)$ & $201(100)$ & & \\
\hline Total & $128(29.4)$ & $307(70.6)$ & $435(100)$ & & \\
\hline
\end{tabular}

${ }^{*}$ Significant. 
to use combined orthodox and traditional health care treatments when compared to respondents whose household heads were traders (OR: 0.27; 0.130 $0.577, \mathrm{p}<0.0001)$. Respondents from a polygamous household were significantly more likely to use combined orthodox and traditional health care treatments when compared to those from a monogamous household (OR: 2.41; 1.411 4.101, $\mathrm{p}=0.001)$. Respondents from households with private water closet toilets were significantly less likely to use combined orthodox and traditional health care treatments when compared to those households that practice open defecation (OR: 0.26; $0.068-0.978, \mathrm{p}=0.047$ ). Respondents from households with a monthly income of greater than 50,000 naira (\$140) were significantly less likely to use combined orthodox and traditional health care treatments when compared to those households with a monthly income of less than 10,000 naira $(\$ 28)$ (OR: 0.36; $0.147-0.894, \mathrm{p}=0.024$ ) (Table 8).

\section{Discussion}

This study assessed the health care knowledge, attitude towards seeking health care and the predictors of using combined orthodox and traditional health care treatments.

In our communities, the lack of awareness of what appropriate health care is, still constitutes an important barrier to seeking appropriate health care, as observed in the present study where close to one third of the respondents did not know what appropriate health care is and even though, most were aware of a modern health facility in their community which was similar to the study by Musoke et al. [18], about $15 \%$ - 30\% of the respondents in the present study also regarded traditional healing homes, churches and spiritual healing homes as sources of treatment. Furthermore, a study among pregnant women in Nigeria [19] reported that, as high as $50 \%-60 \%$ of the respondents were of the opinion that fasting and prayers and other spiritual interventions could be used as a source of treatment.

For those that knew what appropriate health care is, just above half were informed through television and radio media with less than half receiving information from health care staff. This was contrary to a study by Aboyade et al. [20] who reported that, the most common sources of health information were doctors and nurses before radio and television. This may explain to some extent why just above half of the respondents in the present study had an overall moderate to good level of health care knowledge, as it appears that the opportunities of educating patients on appropriate health care during health contact visits are not maximized by the health care workers. This is probably because, it has been wrongly assumed that since the patients have presented themselves to receive modern treatments, that traditional treatments will not be used in the course of the same illness; or probably due to the fact that, they are inadequately staffed or equipped to regularly educate the patients. A study by Ige et al. [21] reported that, previous education about illness by health care workers was significantly associated with the use of modern health care treatments. So educating our 
Table 8. Predictors of combined use of modern and traditional health care treatment.

\begin{tabular}{|c|c|c|c|}
\hline & OR (estimate) & $95 \%(\mathrm{CI})$ & p-value \\
\hline \multicolumn{4}{|c|}{ Educational level of respondents } \\
\hline None & 1.00 & - & \multirow{2}{*}{1.00} \\
\hline Primary & 0.60 & $0.070-5.136$ & \\
\hline Secondary & 0.60 & $0.133-2.700$ & 0.713 \\
\hline Tertiary & 0.19 & $0.045-0.813$ & $0.026^{*}$ \\
\hline \multicolumn{4}{|c|}{ Occupation of respondents } \\
\hline Student & 1.00 & - & - \\
\hline Trader & 2.06 & $1.134-3.733$ & $0.016^{*}$ \\
\hline Civil servant & 0.83 & $0.427-1.614$ & 0.584 \\
\hline Professional & 0.59 & $0.282-1.246$ & 0.165 \\
\hline Others & 1.82 & $0.773-4.297$ & 0.166 \\
\hline \multicolumn{4}{|c|}{ Gender of Household Head } \\
\hline Male & 1.00 & - & - \\
\hline Female & 2.29 & $1.207-4.332$ & $0.010^{*}$ \\
\hline \multicolumn{4}{|c|}{ Occupation of Household Head } \\
\hline Trader & 1.00 & - & - \\
\hline Civil servant & 1.10 & $0.688-1.755$ & 0.699 \\
\hline Professional & 0.27 & $0.130-0.577$ & $0.000^{*}$ \\
\hline Others & 1.19 & $0.541-2.619$ & 0.663 \\
\hline \multicolumn{4}{|c|}{ Educational level of Household Head } \\
\hline None & 1.00 & - & - \\
\hline Primary & 3.03 & $0.644-14.257$ & 0.276 \\
\hline Secondary & 2.56 & $0.664-9.874$ & 0.160 \\
\hline Tertiary & 1.04 & $0.280-3.895$ & 1.000 \\
\hline \multicolumn{4}{|l|}{ Household family type } \\
\hline Monogamous & 1.00 & - & - \\
\hline Polygamous & 2.41 & $1.411-4.101$ & $0.001^{*}$ \\
\hline \multicolumn{4}{|c|}{ Household toilet facilities } \\
\hline Open defecation & 1.00 & - & - \\
\hline Private water closet & 0.26 & $0.068-0.978$ & $0.047^{*}$ \\
\hline Shared water closet & 2.40 & $0.527-10.928$ & 0.411 \\
\hline Pit latrine & 0.34 & $0.068-1.743$ & 0.237 \\
\hline \multicolumn{4}{|c|}{ Household monthly income (Naira) } \\
\hline$<10,000$ & 1.00 & - & - \\
\hline $10,000-50,000$ & 1.17 & $0.526-2.587$ & 0.708 \\
\hline$>50,000$ & 0.36 & $0.147-0.894$ & $0.024^{*}$ \\
\hline Cannot estimate & 0.82 & $0.381-1.745$ & 0.597 \\
\hline
\end{tabular}

communities on appropriate health care will continue to remain an important approach even though, we know that only health care education will not influence health seeking behaviour, but it will provide the foundation for implementing other effective strategies. However, the indecision of individuals about 
health care further provides an opportunity for intervention with health care education in order to influence opinion.

These opportunities were obvious in the present study, where more than half of the respondents were either in agreement or undecided about traditional drugs being more effective than orthodox drugs in treating most diseases; or where close to one quarter of the respondents were either in agreement or undecided about buying drugs from a chemist without a prescription; or where more than one third of the respondents were either in agreement or undecided about receiving a prescription from a laboratory scientist in the absence of a doctor and finally, where close to one third of the respondents were either in agreement or undecided about seeking health care from the church or spiritual healing homes when sick.

In the present study, almost all of the respondents had a moderate to good level of positive attitude towards seeking health care and this is not surprising because, they willingly sought health care irrespective of the type, which could be implied from the fact that, up to $95 \%$ of the respondents sought one type of health care service or the other, ranging from orthodox health care services and self-medication, to spiritual and traditional interventions; as close to half of the respondents in the present study were of the opinion that, what is important, is to seek health care and not where you seek care first.

About three fifths of the respondents in the present study sought treatment first, either from a private hospital or by self-medicating using home treatments and this was not consistent with some other studies [18] [21] [22] [23]. In an Ugandan study [18], close to two thirds had sought treatment from a public health facility and less than one quarter opted for self-medication using drugs from drug shops; but with respect to traditional healers, only $2 \%$ admitted seeking treatment from a traditional healer which was consistent with the present study. In a Nigerian study [22], more than three fifths of the respondents sought treatment by self-medication using drugs from patent medicine stores followed by traditional healers, public health centers and private health clinics; with their commonest reason for preferred choice of visit being accessibility to the health service. This was also different from the present study, where the commonest reasons included the need to receive fast care and personal attention. Also inconsistent, was a study among the Nigerian elderly [23] where close to three quarters of the respondents sought treatment from hospitals and health centers while about $6 \%$ sought treatment from traditional healers. Similarly, in another study among Nigerian market traders [21] which was also inconsistent, observed that, treatment was sought first from self-medication using drugs from patent dealers followed by consultations with health workers, then herbalist as the least option.

However, the preferential use of private hospitals was consistently observed in a study [24] among people in a university community where it was reported that most of them patronized private health care services but this, was not similarly 
observed in the study done by Ilesanmi et al. [25], where the respondents, who were hospital cleaners, mostly patronized the government hospitals followed by Chemist shops with a few utilizing the private health care services. In these cases, socioeconomic status and probably the level of education, may have contributed to the type of health care services that were preferentially utilized, with people in a higher socioeconomic class tending to use private health care services. According to Nabyonga et al. [26], rich people have the choice of utilizing private health care services because of their financial ability to pay.

Most of the respondents in the present study, strongly agreed that it is important to seek health care early when sick with more than two thirds of the respondents, actually reporting, that they usually seek treatment within 3 days of any illness. With respect to attitude, this was similarly observed in the study by Adekanle et al. [19] who reported that, the majority of their respondents were also of the opinion that early presentation to a health facility when sick was necessary. On the contrary, other studies [27] [28] have reported delays in promptly and appropriately seeking treatment when sick; and this has been associated with poor health seeking behaviour. This is from the fact that, a majority are first inappropriately managed at home or within the community, therefore, resulting in delays in receiving treatment from modern health care services.

In the present study, though most of the respondents preferred receiving treatments from modern health care services, close to half of them indulged in self-medication with about $29.4 \%$ of the respondents using combined orthodox and traditional treatments. This observed prevalence of combined use was consistent with an earlier comparative study done in Nigeria [12] that reported a prevalence of $31 \%$. On the contrary, these prevalence rates were not consistently observed in some other Nigerian studies [13] [14] that reported prevalence rates of $61.4 \%$ and $63.7 \%$ respectively. The marked differences observed across these studies may be attributed to the differing sociodemographic and economic characteristics of the different study respondents; as according to Adibe et al. [13], combined use of orthodox and traditional treatments is significantly associated with demographic and socioeconomic characteristics of the respondents.

In the present study, the sociodemographic factors such as the educational level and occupation of the respondents were significantly associated with the use of combined modern and traditional health care treatments. This observed association of combined use with the level of respondents' education, was similar in the study by Adibe et al., but with respect to age and gender of the respondents, their associations with combined use were not consistent. On the other hand, the study by Duru et al. [14] conducted in Orlu Local Government Area in the western part of Imo State, reported that age, gender, marital status, educational level and occupation of the respondents were significantly associated with combined use, of which only the associations of educational level and occupation of the respondents were consistent with the present study. In terms of household characteristics, Duru et al. reported that household size and number 
of children per household were significantly associated with combined use and these relationships were not similarly observed in the present study.

Furthermore, the two studies were conducted in Imo State with the present study being conducted in the Eastern part, within a study area categorized as semi-urban/urban as against the rural/semi-urban study area of Duru et al. conducted in the Western part. The nature of the different study areas obviously reflects on the characteristics of the household and the socio-cultural attitudes and beliefs which in turn, influences health seeking behaviour. Also, the sociodemographic characteristics of the respondents were different with respect to gender, marital status, level of education and occupation; showing different associations and risks of combined use. These varying factors highlights the role of sociodemographic and household characteristics in influencing the use of combined modern and traditional treatments as exemplified in the present study; were being a female, trader and from a polygamous household were significantly more likely to use combined modern and traditional health care treatments and while having a tertiary level of education, from a household whose head is a professional using private water closet toilet facilities and earning a monthly income of more than 50,000 Naira (\$140) were significantly less likely to use combined modern and traditional health care treatments.

\section{Conclusion}

This study observed some level of poor health seeking behaviour and attitude from some of the households studied, thus it is important to organize the provision of health care services in such a way, as to safely guide the interaction of individuals, families and the communities with the different health care treatments and services. It is also important that the health care professionals are equipped with better insight and appreciation of the health care utilization patterns and the sociodemographic and household risk factors associated with using combined orthodox and traditional treatments. Notwithstanding, the use of combined orthodox and traditional treatments in our environment, will be difficult to prevent in spite of its potential harm; because this behaviour is rooted in the traditional and cultural belief system of our societies. Furthermore, the need to be more sensitive to the realities of the use of combined orthodox and traditional treatments is increasingly being recognized, as dismissal by health care professionals of its use among patients, will not influence patient utilization; but rather, it will reduce the opportunities the health care professionals have, to provide safe guidance and control.

\section{Authors' Contributions}

All the authors participated in the study.

\section{Conflict of Interest}

The authors hereby declare that there are no conflicts of interest. 


\section{Source of Funding}

There was no external source of funding.

\section{Acknowledgements}

We thank all the participants in this study and the research assistants who helped during the data collection.

\section{References}

[1] Mazzilli, C and Davis, A. (2009) Health Care Seeking Behaviour in Somalia: A Literature Review. UNICEF, 10.

https://www.unicef.org/somalia/SOM HealthcareseekingbehaviourReport 10-WEB .pdf

[2] Van der Hoeven, M., Kruger, A. and Greeff, M. (2012) Differences in Health Care Seeking Behaviour between Rural and Urban Communities in South Africa. International Journal for Equity in Health, 11, 31. https://doi.org/10.1186/1475-9276-11-31

[3] Ahmed, S., Sobhan, F., Islam, A and Barkat-e-Khuda (2001) Neonatal Morbidity and Care-Seeking Behaviour in Rural Bangladesh. Journal of Tropical Paediatrics, 47, 98-105. https://doi.org/10.1093/tropej/47.2.98

[4] Awusabo-Asare, K. and Anarfi, J.K. (1997) Health-Seeking Behaviour of Persons with HIV/AIDS in Ghana. Health Transition Review, 7, 243-256.

[5] Tinuade, O., Iyabo, R.A. and Durotoye, O. (2010) Health-Care-Seeking Behaviour for Childhood Illnesses in a Resource-Poor Setting. Journal of Paediatrics and Child Health, 46, 238-242. https://doi.org/10.1111/j.1440-1754.2009.01677.x

[6] World Health Organization (WHO) (2002) WHO Traditional Medicine Strategy 2002-2005. World Health Organization, Geneva.

[7] Abubakar, A., Van Baar, A., Fischer, R., Bomu, G., Gona, J.K. and Newton, C.R. (2013) Socio-Cultural Determinants of Health-Seeking Behaviour on the Kenyan Coast: A Qualitative Study. PLoS ONE, 8, e71998. https://doi.org/10.1371/journal.pone.0071998

[8] UNICEF (1998) Somali Health Knowledge, Attitude and Practices. North-West Zone. UNICEF Somalia, Garowe.

[9] Steen, T.W. and Mazonde, G.N. (1999) Ngaka ya Setswana Ngaka ya Sekgoa or both? Health Seeking Behavior in Botswana with Pulmonary Tuberculosis. Social Science and Medicine, 48, 163-172. https://doi.org/10.1016/S0277-9536(98)00329-3

[10] Outwater, A., Nkya, L., Lyamuya, E., Luihula, G., Green, E.C., Hogle, J., et al. (2001) Health Care Seeking Behaviour for Sexually Transmitted Diseases among Commercial Sex Workers Culture. Health and Sexuality, 3, 19-33. https://doi.org/10.1080/136910501750035653

[11] MacKian, S. (2003) A Review of Health Seeking Behaviour: Problems and Prospects. University of Manchester, Health Systems Development Programme. https://assets.publishing.service.gov.uk/media/57a08d1de5274a27b200163d/05-03 health seeking behaviour.pdf

[12] Osemene, K.P., Ejuoba, A.A. and IIori, M.O.A. (2011) A Comparative Assessment of Herbal and Orthodox Medicines in Nigeria. Research Journal of Medical Sciences, 5, 280-285. https://doi.org/10.3923/rjmsci.2011.280.285

[13] Adibe, M.O. (2009) Prevalence of Concurrent Use of Herbal and Synthetic Medi- 
cines among Out Patients in a Mission Hospital in Nigeria. International Journal of Drug Development and Research, 1, 60-66.

[14] Duru, C.B., Diwe, K.C., Uwakwe, K.A., Duru, C.A., Merenu, I.A., Iwu, A.C., et al. (2016) Combined Orthodox and Traditional Medicine Use among Households in Orlu, Imo State, Nigeria; Prevalence and Determinants. World Journal of Preventive Medicine, 4, 5-11.

[15] Singer, M., Davidson, L. and Gerdes, G. (1988) Culture, Critical Theory, and Reproductive Illness Behavior in Haiti. Medical Anthropology Quarterly, 2, 370-385. http://onlinelibrary.wiley.com/doi/10.1525/maq.1988.2.4.02a00060/abstract;jsession $\mathrm{id}=$ A803D74FF8A36BF9EA4DAA6ED858FA13.f03t04 https://doi.org/10.1525/maq.1988.2.4.02a00060

[16] National Population Commission (2006) Federal Republic of Nigeria 2006 Population and Housing Census: Priority Table Volume III.

http://www.population.gov.ng/images/Vol\%2003\%20Table\%20DSx\%20LGAPop\%2 0by\%20SDistrict-PDF.pdf

[17] Cochran, W.G. (1963) Sampling Technique. 2nd Edition, John Wiley and Sons Inc., New York.

[18] Musoke, D., Boynton, P., Butler, C. and Musoke, M.B. (2014) Health Seeking Behaviour and Challenges in Utilizing Health Facilities in Wakiso District, Uganda. African Health Sciences, 14, 1046-1055. https://doi.org/10.4314/ahs.v14i4.36

[19] Adekanle, D.A., Adeyemi, A.S., Akinleye, C.A. and Daramola, O.P. (2014) Knowledge and Health Seeking Behaviour of Nigerian Pregnant Women towards PreEclampsia. Research Journal of Health Sciences, 2, 1. http://www.rjhs.uniosun.edu.ng/index.php/rjhs/article/view/75

[20] Aboyade, O.M., Beauclair, R., Mbamalu, O.N., Puoane, T.R. and Hughes, G.D. (2016) Health-Seeking Behaviors of Older Black Women Living with Non-Communicable Diseases in an Urban Township in South Africa. BMC Complementary and Alternative Medicine, 16, 410. https://doi.org/10.1186/s12906-016-1378-4

[21] Ige, K. and Nwachukwu, C. (2008) Health Care Seeking Behaviour among Market Traders in Ibarapa Central Local Government, Nigeria. The Internet Journal of Health, 9, 2.

[22] Chukwuneke, F.N., Ezeonu, C.T., Onyire, B.N., Ezeonu, P.O., Ifebunandu, N. and Umeora, M.C. (2012) Health Seeking Behaviour and Access to Health Care Facilities at the Primary Level in Nigeria: Our Experience. Ebonyi Medical Journal, 11, 51-57.

[23] Odaman, O.M. and Ibiezugbe, M.I. (2014) Health Seeking Behavior among the Elderly in Edo Central Nigeria. International Review of Social Sciences and Humanities, 7, 201-210.

[24] Tanimola, M.A. and Julius, O.O. (2009) Health Seeking Behaviour in Anyigba, North-Central, Nigeria. Research Journal of Medical Sciences, 3, 47-51.

[25] Ilesanmi, O.S., Omotoso, B.A., Ayodeji, O.O. and Falana, D.T. (2014) Health Problems and Health Seeking Behaviour of Hospital Cleaners in a Tertiary Health Facility in South West Nigeria. Academic Journal of Interdisciplinary Studies, 3, 187192.

[26] Nabyonga, O.J., Mugisha, F., Okui, A.P., Musango, L. and Kirigia, J.M. (2013) Health Care Seeking Patterns and Determinants of Out-of-Pocket Expenditure for Malaria for the Children Under-Five in Uganda. Malaria Journal, 12, 175. https://doi.org/10.1186/1475-2875-12-175 
[27] Warsame, M., Kimbute, O., Machinda, Z., Ruddy, P., Melkisedick, M., Peto, T., et al. (2007) Recognition, Perceptions and Treatment Practices for Severe Malaria in Rural Tanzania: Implications for Accessing Rectal Artesunate as a Pre-Referral. PLOS ONE, 2, e149. https://doi.org/10.1371/journal.pone.0000149

[28] Chibwana, A., Mathanga, D., Chinkhumba, J. and Campbell, C.H. (2009) SocioCultural Predictors of Health-Seeking Behaviour for Febrile Under-Five Children in Mwanza-Neno District, Malawi. Malaria Journal, 8, 219.

https://doi.org/10.1186/1475-2875-8-219

\section{Submit or recommend next manuscript to SCIRP and we will provide best} service for you:

Accepting pre-submission inquiries through Email, Facebook, LinkedIn, Twitter, etc. A wide selection of journals (inclusive of 9 subjects, more than 200 journals)

Providing 24-hour high-quality service

User-friendly online submission system

Fair and swift peer-review system

Efficient typesetting and proofreading procedure

Display of the result of downloads and visits, as well as the number of cited articles

Maximum dissemination of your research work

Submit your manuscript at: http://papersubmission.scirp.org/

Or contact ojpm@scirp.org 